\title{
Evidence of Marine Microplastics in Commercially Harvested Seafood
}

OPEN ACCESS

Edited by:

Maria José Saavedra, Universidade de Trás-os-Montes e

Alto Douro, Portugal

Reviewed by:

Sonia Gomes,

University of Trás-os-Montes and Alto

Douro, Portugal

Simone Graça Pinto Varandas,

University of Trás-os-Montes and Alto

Douro, Portugal

Marisa Almeida,

Interdisciplinary Centre of Marine and Environmental Research,

University of Porto, Portugal

*Correspondence:

Emily Curren

e0013223@u.nus.edu

${ }^{t}$ These authors have contributed equally to this work

Specialty section:

This article was submitted to

Biosafety and Biosecurity,

a section of the journal

Frontiers in Bioengineering and

Biotechnology

Received: 18 May 2020

Accepted: 12 November 2020

Published: 04 December 2020

Citation:

Curren E, Leaw CP, Lim PT and

Leong SCY (2020) Evidence of Marine

Microplastics in Commercially

Harvested Seafood.

Front. Bioeng. Biotechnol. 8:562760.

doi: 10.3389/fbioe.2020.562760

\section{Emily Curren ${ }^{1 * t}$, Chui Pin Leaw ${ }^{2 t}$, Po Teen Lim ${ }^{2+}$ and Sandric Chee Yew Leong ${ }^{1+}$}

1'St. John's Island National Marine Laboratory, Tropical Marine Science Institute (TMSI), National University of Singapore, Singapore, Singapore, ${ }^{2}$ Bachok Marine Research Station, Institute of Ocean and Earth Sciences, University of Malaya, Bachok, Malaysia

Microplastic pollution is a global issue that has a detrimental impact on food safety. In marine environments, microplastics are a threat to marine organisms, as they are often the same size range as prey and are mistaken as food. Consumption of microplastics has led to the damage of digestive organs and a reduction in growth and reproductive output. In this study, microplastic pollution was assessed across three commercially available shrimp species that were obtained from the supermarkets of Singapore. A total of 93 individuals were studied from the Pacific white leg shrimp, Litopenaeus vannamei, the Argentine red shrimp Pleoticus muelleri and the Indian white shrimp Fenneropenaeus indicus. Microplastic fibers, fragments, film and spheres were identified from the digestive tract of these organisms. Microplastic abundance ranged from 13.4 to 7050 items. F. indicus exhibited the highest number of microplastics. Microplastic film was the most abundant in L. vannamei individuals (93-97\%) and spheres were the most abundant in P. muelleri (70\%) and F. indicus (61\%) individuals. This study demonstrates that microplastic contamination is evident in commonly consumed shrimp and highlights the role of shrimp in the trophic transfer and accumulation of microplastics in seafood. The consumption of microplastic-containing seafood is a route of exposure to humans and has implications on human health and food security. Capsule: Microplastics were examined in three shrimp species from the supermarkets of Singapore. Microplastics ranged from 13.4 to 7050 items of shrimp.

Keywords: seafood, microplastic, commercial, marine, pollution, shrimp

\section{INTRODUCTION}

Plastic pollution is a global problem of the 21st century. In marine environments, microplastics are widespread and are found in many coastal waters and even in large water bodies such as the Pacific (Desforges et al., 2014), Atlantic (Enders et al., 2015), and the Arctic (Lusher et al., 2015). Microplastics can exist as primary microplastics, which are round plastic nurdles or pellets, which are used for pre-production of larger plastic particles. Primary microplastics also exist in the form of microbeads, which were once highly popular in cosmetics such as facial cleansers and toothpastes (Napper et al., 2015). Microfibers from the effluent of washing machines also constitute primary microplastics (Kalčíková et al., 2017). Due to the small size of these particles, microplastics will evade sewage treatment and be discharged directly into the marine environment through wastewater (Pirc et al., 2016). Secondary microplastics are formed from degradation and 
fragmentation of larger plastic particles such as foam buoys and fishing gear due to physical, biological and chemical processes (Andrady, 2011).

Due to their small size, these plastic particles are a threat to marine life as they are often mistaken as food (Neves et al., 2015). The ingestion of microplastics has been recorded across many marine organisms, from worms (Wright et al., 2013), larvae of oysters (Cole and Galloway, 2015) and fish (Mazurais et al., 2015; Steer et al., 2017), mussels (Van Cauwenberghe et al., 2015), crabs (Watts et al., 2014), sharks (Alomar and Deudero, 2017) and whales (Lusher et al., 2015). Microplastic ingestion is detrimental, as it has led to the physical injury in organisms (Gall and Thompson, 2015), internal obstruction (Guzzetti et al., 2018), affecting their feeding behavior, reproduction and growth, In addition, the surfaces of microplastics contains heavy metals such as copper and zinc (Brennecke et al., 2016), which are harmful and can bioaccumulate in the tissues of marine animals (Jakimska et al., 2011). Leachates from these plastics contain many additives and are known to be acutely toxic to copepods (Bejgarn et al., 2015), algae (Luo et al., 2019) and gastropods (Seuront, 2018). These microplastics in the marine environment are causing harm to many wildlife organisms including marine mammals and could even result in mortalities.

The prevalence of microplastics in marine environments directly impacts commercial fisheries and aquaculture industries (Lusher et al., 2017a). Smaller commercial seafood such as shrimps or decapod crustaceans are more likely to be impacted by microplastics as compared to larger fish, because microplastics fall in a similar size range to the prey or foods of shrimp. Shrimps are filter-feeders and feed on food matter using their pereiopod (Nimrat et al., 2011) and will consume everything in their path. As a result, shrimp end up ingesting these particles by mistake and accumulate microplastics in their intestines. The accumulated microplastics will affect the safety of seafoods.

In the marine aquaculture industry, shrimp farming is commercially viable and has been adopted by over 60 countries around the world (Jory and Cabrera, 2012), including Brazil (Rebouças et al., 2011), Thailand (Nimrat and Vuthiphandchai, 2011) and Vietnam (Hai et al., 2015). In marine environments, shrimps prey on smaller organisms such as copepods (MatiasPeralta et al., 2012) and fish larvae (Theilacker and Lasker, 1974), which are also known to take in microplastics (Desforges et al., 2015; Steer et al., 2017). On the other hand, shrimps are the prey for larger marine animals such as fish (Mace and Rozas, 2018) and whale sharks (Rohner et al., 2015). Shrimps are also common and popular seafood, where many people consume them whole without gut removal. Hence, human consumption of shrimps contaminated with microplastics form a direct route of exposure, posing a threat to food security and human health. This highlights the potential role of shrimp in the trophic transfer and accumulation of microplastics in seafood.

Singapore is an island nation that produces only a small percentage of its fresh food and is largely reliant on imports, especially for seafood (Tey et al., 2009; Tortajada and Zhang, 2016). Shrimp in Singapore supermarkets originate from neighboring regions such as Malaysia, Indonesia and Vietnam, as well as from other countries such as Argentina and Australia.
These shrimps are popular as seafood and commonly available in local supermarkets. For wild shrimps, there have been a few reports regarding microplastic contamination (Devriese et al., 2015; Daniel et al., 2020; Hossain et al., 2020). However, there have not been any studies investigating the presence of microplastics in commercially available shrimp in Singapore. Hence, this study aimed to elucidate the abundance and characteristics of microplastic contamination in different species of shrimp consumed in Singapore. In this study, three species of commercially farmed shrimp; the Pacific white leg shrimp, Litopenaeus vannamei, the Argentine red shrimp Pleoticus muelleri and the Indian white shrimp Fenneropenaeus indicus were examined for the contamination by microplastics.

\section{MATERIALS AND METHODS}

\section{Sample Collection}

Three species of shrimp with origins from four locations were purchased from the supermarkets of Singapore in January 2020. L. vannamei, $P$. muelleri, and $F$. indicus were the shrimp species studied. A total of 93 individuals were sampled, with 30 individuals of L. vannamei, 15 individuals of P. muelleri and 18 individuals of $F$. indicus. These shrimps were imported from various countries such as Malaysia, Ecuador, Southwest Atlantic and the Indian Ocean (Table 1). These shrimp were obtained in frozen form or were thawed before purchase. Whole shrimp were used in this study, and were not deshelled or cooked before processing. Prior to experimentation, the shrimps were thawed in room temperature for $1 \mathrm{~h}$, each shrimp washed with $200 \mathrm{ml}$ of Milli-Q water (Merck, Millipore) and placed on clean stainless steel trays using metal forceps. The wet weight of each individual was measured using aluminum weighing boats and averaged (Table 1). Shrimps were deshelled and dissected on metal trays using metal forceps and a metal scissors. The metal forceps and scissors were washed with Milli-Q water after processing each batch of shrimps. The gastrointestinal (GI) tract was removed using metal forceps and transferred to a $100 \mathrm{ml}$ glass jar. Three replicates were conducted for each species of shrimp (Table 1).

\section{Contamination Control}

During the experiment, shrimps were dissected and processed in a clean-air cabinet to reduce contamination. Cotton clothing, lab coats, nitrile gloves were worn during the study. Work surfaces and tools such as metal trays, metal spoons and forceps were cleaned with $70 \%$ ethanol and then rinsed with Milli-Q water before use. As far as possible, glass and metal wares were used to reduce introduction of plastic from the surrounding. For each shrimp sample studied, a black extraction control was performed without shrimp tissue to correct for any procedural contamination. This control was placed inside the clean-air cabinet while experimental procedures were carried out to account for microplastic contamination from surrounding air. Sodium hypochlorite and sodium chloride solutions were filtered using a sterile $0.22 \mu \mathrm{m}$ syringe filter (Merck, Millipore) before use. 
TABLE 1 | Abundance of microplastics in different groups of shrimp.

\begin{tabular}{|c|c|c|c|c|}
\hline Species & Location & Number of individuals studied & Average wet weight (g w.w.) & $\begin{array}{l}\text { Average number of } \\
\text { microplastics/g w.w. }\end{array}$ \\
\hline \multirow[t]{2}{*}{ Litopenaeus vannamei } & Malaysia & 30 & $23 \pm 1$ & $21 \pm 4$ \\
\hline & Ecuador & 30 & $29 \pm 2$ & $13 \pm 1$ \\
\hline Pleoticus muelleri & Argentina Southwest Atlantic, FAO 41 & 15 & $56 \pm 4$ & $7050 \pm 418$ \\
\hline Fenneropenaeus indicus & Indian ocean, FAO 57 & 18 & $38 \pm 1$ & $5570 \pm 100$ \\
\hline
\end{tabular}

\section{Treatment of Soft Tissue With Sodium Hypochlorite}

The extraction of microplastics from the GI tracts of shrimps was performed using $6.25 \%$ of filtered sodium hypochlorite $(\mathrm{NaClO}$; Sujathan et al., 2017). $50 \mathrm{ml}$ of $\mathrm{NaClO}$ was added to each glass bottle to break down the soft tissue. $\mathrm{NaClO}$ was chosen as the digesting solution as it is effective in digesting organic matter (Karami et al., 2017). Furthermore, other solutions such as nitric acid and hydrochloric acid are able to degrade polymers and hence are not suitable for this purpose. The glass bottles were covered with sheets of aluminum foil and placed on a flat surface at $25^{\circ} \mathrm{C}$ for $48 \mathrm{~h}$ for digestion to take place (Lusher et al., 2017b).

\section{Density Separation Using $\mathrm{NaCl}$ Solution}

$80 \mathrm{ml}$ of saturated salt solution of pre-filtered $1.2 \mathrm{~g} / \mathrm{ml}$ of sodium chloride was added to the glass jar containing digested shrimp matter for density separation of microplastics (Hidalgo-Ruz et al., 2012; Li et al., 2015). A metal spatula was used to mix the solution and left for $24 \mathrm{~h}$. This enables the separation of less dense microplastics from denser organic matter such as sand and metal pieces. The top layer of solution was then gently removed and transferred into clean glass petri dishes for microscopic observation. All experimentation procedures were completed within 4 weeks of shrimp processing.

\section{Identification and Analysis of Microplastics}

Microplastics were observed under an inverted Nikon microscope. Microplastics were assessed visually and categorized by different morphotypes such as fiber, sphere, film and fragments according to their physical characteristics. The number of microplastics were quantified and recorded.

\section{Statistical Analyses}

Differences in microplastic abundance in shrimp types were tested using one-way analysis of variance (ANOVA) followed by Tukey's HSD post hoc pairwise comparisons. A significance level of 0.01 was chosen. Statistical analyses were run using the 'multcomp' package (Hothorn et al., 2016) in R studio (version 1.3.1073). Reported values were corrected to three significant figures when necessary.

\section{RESULTS}

In this study, three species of marine shrimp, L. vannamei, $P$. muelleri and F. indicus, from four locations, Malaysia, Ecuador,
Southwest Atlantic and the Indian Ocean were obtained from the supermarkets of Singapore and studied for their presence of microplastics. A total of 93 shrimps were sampled (Table 1). Microplastic fibers, fragments, film and spheres were detected in L. vannamei, P. muelleri and F. indicus. Pink and blue colored fibers and fragments were commonly observed. Procedural blanks revealed an average of 6 microplastics per sample, and were mostly uncolored translucent fibers.

The average wet weight of one individual of $L$. vannamei from Malaysia was $23 \pm 1 \mathrm{~g}$ w.w (Table 1). A total of 14186 microplastic particles were observed in 30 individuals, with an average of $21 \pm 4 / \mathrm{g}$ w.w. From this sample, film particles were the most abundant (97.9\%; Figure 1A), followed by fragments $(0.8 \%)$. Fibers and spheres were of similar abundances at $0.6 \%$.

Individuals of L. vannamei from Ecuador were also studied, with the average weight of one individual being $29 \pm 2 \mathrm{~g}$ w.w. (Table 1). A total of 11625 pieces of microplastics were observed among 30 individuals, with an average of $13 \pm 1$ /g w.w. (Table 1). From this sample, film microplastics were the most abundant (93\%), followed by fragments $(4.7 \%)$, fibers $(2 \%)$ and spheres $(0.3 \%)$ (Table 2 and Figure 2). Film microplastics collected were mostly transparent, with the exception of some that were colored (Figure 1B).

The average weight of one individual of $P$. muelleri was $56 \pm 4$ g w.w. (Table 1). A total of 5,867,833 pieces of microplastics were obtained from 15 individuals of $P$. muelleri, with an average of $7050 \pm 4178 / \mathrm{g}$ w.w. of microplastics. When examined, one shrimp individual had white colored spheres, which were visible from the outside of the intestine. These spheres were as large as $500 \mu \mathrm{m}$ in diameter (Figure 1C). From this sample, spheres were the most abundant (69.6\%), followed by fragments $(21.5 \%)$, film $(7.4 \%)$ and fibers (1.5\%) (Table 2 and Figure 2). These spheres were mostly opaque and ranged from 10-20 $\mu \mathrm{m}$ in diameter (Figure 1F). An agglomeration of spheres was also observed in this sample (Figure 1D).

The average wet weight of one individual of $F$. indicus was $38 \pm 1 \mathrm{~g}$ w.w (Table 1). In 18 individuals of F. indicus, 3,763,750 microplastic particles were recorded, with an average number of $5570 \pm 100 / \mathrm{g}$ w.w. (Table 2). Microplastic spheres were the most abundant in this sample (61.6\%), Film and fragment microplastics were $25.4 \%$ and $10.8 \%$ respectively. Fibers were the least abundant at 2.2\% (Table 2; Figure 2). Blue colored fibers were observed in this sample (Figure 1E).

One-way ANOVA analyses demonstrated that the abundance of microplastic fibers, fragments, spheres film and spheres were significantly different when compared between species ( $p$-value $<0.01$; Table 3 ) and also within each shrimp type 


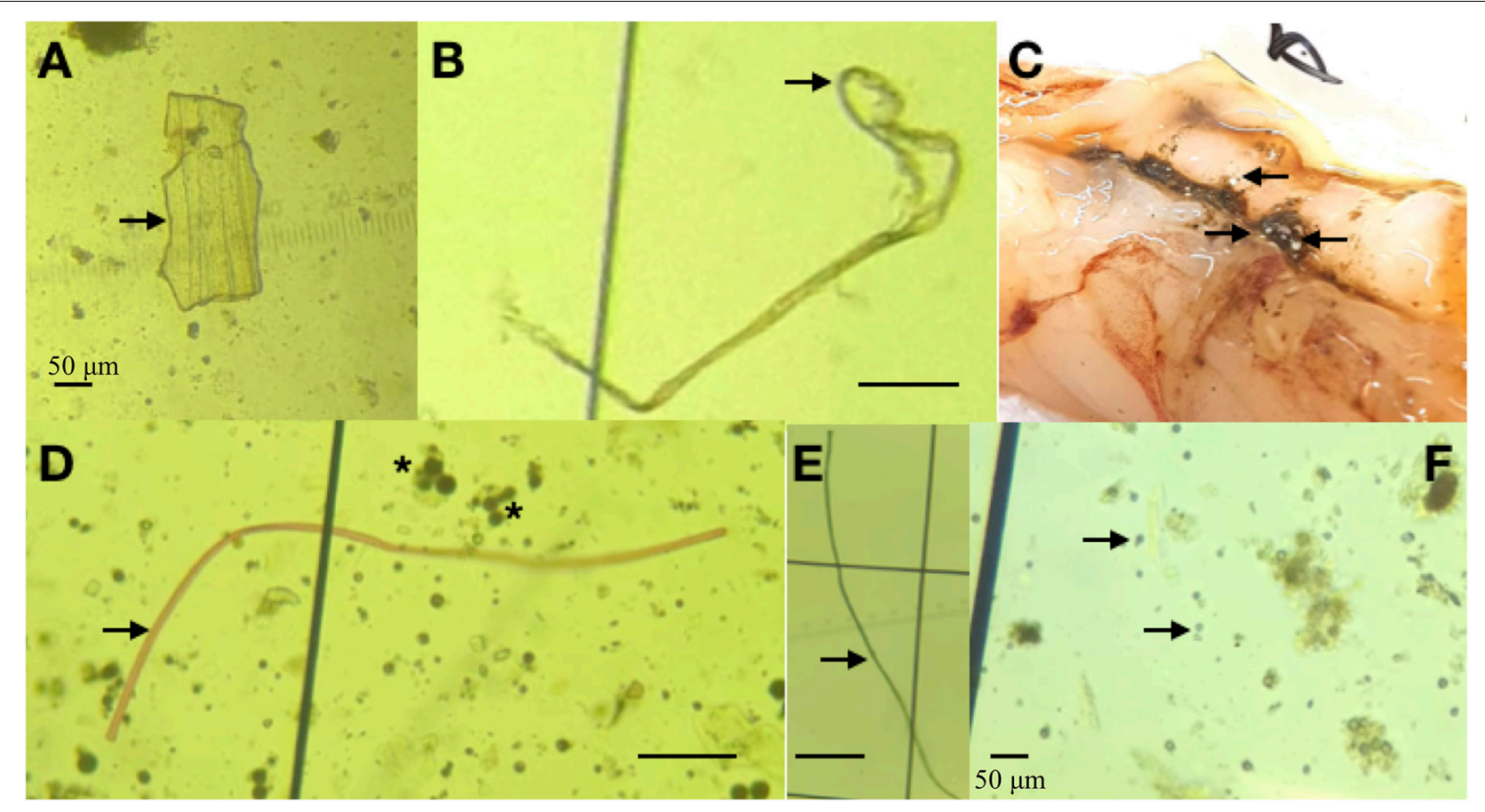

FIGURE 1 | Composition of microplastics in L. vannamei shrimp (Malaysia, Ecuador), P. muelleri (Atlantic Ocean) and F. indicus (Indian Ocean). Compositions are in percentages.

TABLE 2 | Abundance of various microplastic types in different groups of shrimp.

\begin{tabular}{|c|c|c|c|c|c|}
\hline Species & Location & Number of fibers /g w.w. & $\begin{array}{c}\text { Number of } \\
\text { fragments /g w.w }\end{array}$ & $\begin{array}{c}\text { Number of film /g } \\
\text { w.w. }\end{array}$ & $\begin{array}{l}\text { Number of spheres /g } \\
\text { w.w. }\end{array}$ \\
\hline \multirow[t]{2}{*}{ L. vannamei } & Malaysia & $1.20 \pm 1.06$ & $1.60 \pm 1.72$ & $205 \pm 37.9$ & $1.31 \pm 0.275$ \\
\hline & Ecuador & $8.66 \times 10^{-3} \pm 6.77 \times 10^{-4}$ & $0.861 \pm 7.41 \times 10^{-2}$ & $25.3 \pm 1.59$ & $8.93 \times 10^{-3} \pm 5.18 \times 10^{-4}$ \\
\hline P. muelleri & Argentina, Southwest Atlantic, FAO 41 & $468 \pm 104$ & $4930 \pm 1110$ & $3190 \pm 643$ & $32800 \pm 793$ \\
\hline F. indicus & Indonesia, Eastern Indian ocean, FAO 57 & $1100 \pm 51.5$ & $4990 \pm 334$ & $8950 \pm 515$ & $21500 \pm 805$ \\
\hline
\end{tabular}

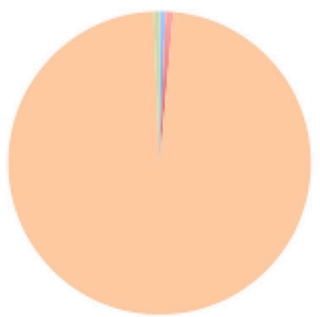

L. vannamei (Malaysia)

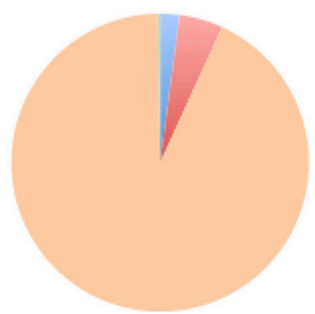

L. vannamei (Ecuador)

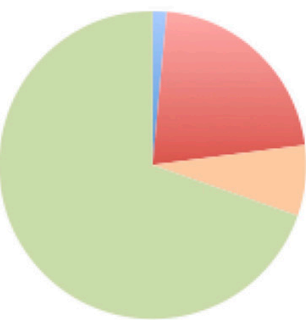

P. muelleri

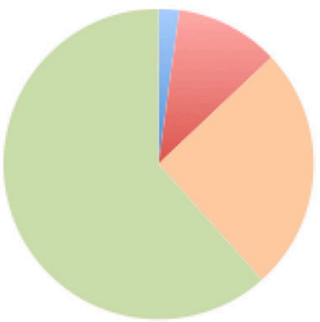

F. indicus (Atlantic Ocean) (Indian Ocean)
Fiber

Fragment:

Film

Sphere

FIGURE 2 | (A-F) Microplastic particles obtained from the digestive tracts of shrimp. (A) Microplastic film from L. vannamei (Malaysia). (B) Microplastic fiber from L. vannamei (Ecuador). (C) White microplastic spheres from P. rnuelleri. (D) Red microplastic fiber from P. rnuelleri (arrow). Agglomerations of microplastic spheres are indicated by the asterisk (*). (E) Blue microplastic fiber from F. indicus. Unless otherwise indicated, scale bars represent $20 \mu \mathrm{m}$.

(p-value $<0.01$; Table 4). Pairwise comparisons of the abundance of each microplastic type were made between species types via Tukey's HSD Post hoc test (Table 5). The abundance of microplastic fibers, fragments, film and spheres were significantly different between shrimp pairs with a few exceptions. There was no significant difference between the abundance of the 
TABLE 3 | Results from one-way ANOVA test for differences in the composition of ingested microplastics between the four shrimp types.

\begin{tabular}{lcccc}
\hline & df & MS & $\boldsymbol{F}$ value & $\boldsymbol{P}$-value \\
\hline Microplastic fiber & 3 & $136 \times 10^{4}$ & 886 & $<0.001^{*}$ \\
Microplastic fragment & 3 & $311 \times 10^{5}$ & 1790 & $<0.001^{*}$ \\
Microplastic film & 3 & $868 \times 10^{5}$ & 691 & $<0.001^{*}$ \\
Microplastic sphere & 3 & $134 \times 10^{7}$ & 10500 & $<0.001^{*}$ \\
\hline
\end{tabular}

TABLE 4 | Results from one-way ANOVA test for differences in the composition of ingested microplastics within each shrimp type.

\begin{tabular}{lcccc}
\hline & df & MS & F value & $P$-value \\
\hline L. vannamei (Malaysia) & 3 & 51800 & 239 & $<0.001$ \\
L. vannamei (Ecuador) & 3 & 785 & 2000 & $<0.001$ \\
P. muelleri & 3 & $114 \times 10^{7}$ & 10300 & $<0.001$ \\
F. indicus & 3 & $389 \times 10^{6}$ & 2120 & $<0.001$ \\
\hline
\end{tabular}

four microplastic types in L. vannamei from Malaysia and Ecuador ( $p$-value $>0.01$; Table 5). There was also no significant difference in the abundance of microplastic fragments collected from $P$. muelleri and F. indicus ( $p$-value $>0.01$; Table 5). The differences in the abundance of microplastic types within each shrimp were also examined (Table 6). In L. vannamei (Malaysia) and L. vannamei (Ecuador), significant differences in microplastic abundances were found between fibers vs film, fragments vs film and film vs spheres ( $p$-value $<0.01$; Table 6). There were significant differences between pairwise comparisons of all types of microplastics in both $P$. muelleri and F. indicus $(p$-value $<0.01$; Table 6)

\section{DISCUSSION}

This study demonstrated that microplastic particles are present in the digestive tracts of three species of shrimp, L. vannamei, $P$. muelleri and F. indicus, which are commercially available in the supermarkets of Singapore. Although microplastics are well-known to be a widespread contaminant in the marine environment, the presence of microplastics in commercially available shrimp has not yet been documented. This is the first study that has documented the presence of microplastics in these commercially available shrimps. The first report of microplastics in marine decapod shrimp species was the European brown shrimp, Crangon crangon of the Southern North Sea (Devriese et al., 2015). C. crangon had an average abundance of $1.23 \pm 0.99$ items/individual (Devriese et al., 2015; Table 7). Subsequently, the presence of microplastics has been investigated in five other marine decapod species including the Gamba shrimp (Aristeus antennatus), black tiger shrimp (P. monodon) and Indian white shrimp (F. indicus) (Table 7). These species have high commercial interest and are commonly consumed seafood by humans (Rosa and Nunes, 2004; Sriket et al., 2007). Although the same species F. indicus was compared from Kerala, India (Daniel et al., 2020) and FAO57, Indian Ocean of this study, both had different microplastic abundances and dominant ingested microplastic type (Table 7). This is likely due to the availability of microplastic type in the environment (Fossi et al., 2014). In the study of Daniel et al. (2020), microplastic fibers were dominant in F. indicus as those individuals were obtained from the coastal region with large amounts of fishing gear and fabric textiles (Kane and Clare, 2019; Robin et al., 2020). In the case of F. indicus from FAO57, spheres were the dominant microplastic type observed (Table 2). However, as FAO57 of the east Indian ocean extends from the Bay of Bengal to Southern Australia, the exact origin of $F$. indicus from this study is unknown and hence no further deductions can be made.

Microplastic fibers, film, fragments and spheres were observed to be present in the GI tracts of shrimp species. Among the species, L. vannamei consumed the least number of microplastics per wet weight regardless of location. Furthermore, there were no significant differences among the different microplastic types in L. vannamei from Malaysia and Ecuador. P. muelleri and F. indicus consumed approximately 200 times more microplastics compared to L. vannamei per wet weight of individual. Both groups of L. vannamei from Malaysia and Ecuador consumed similar concentrations of microplastics. As shrimps are a detritus feeder (Varadharajan and Pushparajan, 2013), this could mean that the abundance of microplastics in the benthic sediments of Malaysia and Ecuador could be similar. The number of ingested microplastics can reflect the abundance of microplastics present in the environment organisms exist in (Fossi et al., 2014; Nel et al., 2018). The abundance of microplastics have been measured in the surface marine waters of Malaysia, at 0.13-0.69 particles/L (Khalik et al., 2018). However, the abundance of microplastics in benthic marine sediments has not yet been studied in Malaysian

TABLE 5 | Results of Tukey's HSD Post hoc test in the composition of ingested microplastic particles between the four shrimp types.

\begin{tabular}{|c|c|c|c|c|c|c|c|c|}
\hline & \multicolumn{2}{|c|}{ Fiber } & \multicolumn{2}{|c|}{ Fragment } & \multicolumn{2}{|c|}{ Film } & \multicolumn{2}{|c|}{ Sphere } \\
\hline & Q statistic & $P$-value & Q statistic & $P$-value & Q statistic & $P$-value & Q statistic & $P$-value \\
\hline L. vannamei (Malaysia) vs. L. vannamei (Ecuador) & 0.058 & 0.899 & 0.007 & 0.899 & 1.23 & 0.801 & 0.007 & 0.899 \\
\hline L. vannamei (Malaysia) vs P. muelleri & 22.8 & $<0.001^{\star}$ & 24.1 & $<0.001^{*}$ & 20.5 & $<0.001^{*}$ & 164 & $<0.001^{*}$ \\
\hline L. vannamei (Malaysia) vs. F. indicus & 53.6 & $<0.001^{\star}$ & 24.3 & $<0.001^{\star}$ & 60.0 & $<0.001^{*}$ & 107 & $<0.001^{*}$ \\
\hline L. vannamei (Ecuador) vs. P. muelleri & 22.8 & $<0.001^{\star}$ & 24.1 & $<0.001^{*}$ & 21.7 & $<0.001^{*}$ & 164 & $<0.001^{*}$ \\
\hline L. vannamei (Ecuador) vs. F. indicus & 53.6 & $<0.001^{\star}$ & 24.4 & $<0.001^{*}$ & 61.2 & $<0.001^{*}$ & 107 & $<0.001^{*}$ \\
\hline P. muelleri vs. F. indicus & 30.8 & $<0.001^{\star}$ & 0.273 & 0.899 & 39.5 & $<0.001^{\star}$ & 57.0 & $<0.001^{*}$ \\
\hline
\end{tabular}

The *indicates significant differences between the species type compared $(p<0.01)$. 
TABLE 6 | Results of Tukey's HSD Post hoc test in the composition of ingested microplastic particles within each shrimp type.

\begin{tabular}{|c|c|c|c|c|c|c|c|c|}
\hline & \multicolumn{2}{|c|}{ L. vannamei (Malaysia) } & \multicolumn{2}{|c|}{ L. vannamei (Ecuador) } & \multicolumn{2}{|c|}{ P. muelleri } & \multicolumn{2}{|c|}{ F. indicus } \\
\hline & Q statistic & $P$-value & Q statistic & $P$-value & Q statistic & $P$-value & Q statistic & $P$-value \\
\hline Fiber vs. fragment & 0.128 & 0.899 & 2.38 & 0.365 & 16.7 & $<0.001^{\star}$ & 21.7 & $<0.001^{\star}$ \\
\hline Fiber vs. film & 30.4 & $<0.001^{\star}$ & 86.3 & $<0.001^{\star}$ & 10.2 & $<0.001^{\star}$ & 43.8 & $<0.001^{\star}$ \\
\hline Fiber vs. sphere & 0.016 & 0.899 & $9 \times 10^{-4}$ & 0.899 & 121 & $<0.001^{\star}$ & 114 & $<0.001^{\star}$ \\
\hline Fragment vs. film & 30.3 & $<0.001^{\star}$ & 83.9 & $<0.001^{\star}$ & 6.53 & $<0.001^{\star}$ & 22.1 & $<0.001^{\star}$ \\
\hline Fragment vs. sphere & 0.112 & 0.899 & 2.38 & 0.365 & 104 & $<0.001^{\star}$ & 91.9 & $<0.001^{\star}$ \\
\hline Film vs. sphere & 30.4 & $<0.001^{\star}$ & 86.3 & $<0.001^{*}$ & 111 & $<0.001^{\star}$ & 69.8 & $<0.001^{*}$ \\
\hline
\end{tabular}

The *indicates significant differences between the microplastic type compared $(p<0.01)$.

TABLE 7 | Studies investigating microplastic presence in marine decapod species.

\begin{tabular}{|c|c|c|c|}
\hline Species & Location & Microplastic abundance & References \\
\hline European brown shrimp (Crangon crangon) & North Sea & $1.23 \pm 0.99$ items/individual & Devriese et al., 2015 \\
\hline \multirow[t]{2}{*}{ Gamba shrimp (Aristeus antennatus) } & $\begin{array}{l}\text { Balearic basin, northwestern } \\
\text { Mediterranean sea }\end{array}$ & $\begin{array}{l}39.2 \% \text { individuals reported to have ingested } \\
\text { microplastics. Fibers dominant }\end{array}$ & Carreras-Colom et al., 2018 \\
\hline & $\begin{array}{l}\text { Sardinia Island, Mediterranean } \\
\text { Sea }\end{array}$ & $\begin{array}{l}1.66 \pm 0.11 \text { pieces/individual; Fragments dominant at } \\
53 \%\end{array}$ & Cau et al., 2019 \\
\hline Green tiger shrimp (Penaeus semisulcatus) & Northeast of Persian Gulf & $0.360 \mathrm{pieces} / \mathrm{g}$ of muscle & Akhbarizadeh et al., 2019 \\
\hline $\begin{array}{l}\text { Indian white shrimp (Fenneropenaeus } \\
\text { indicus) }\end{array}$ & Cochin, Kerala, India & $0.04 \pm 0.07$ pieces/individual Fibers dominant at 83\% & Daniel et al., 2020 \\
\hline Black tiger shrimp (Penaeus monodon) & $\begin{array}{l}\text { Northern Bay of Bengal, } \\
\text { Bangladesh }\end{array}$ & $\begin{array}{l}6.60 \pm 0.2 \text { pieces } / g \text { of gastrointestinal tract Filaments } \\
\text { dominant at } 57 \%\end{array}$ & Hossain et al., 2020 \\
\hline Brown shrimp (Metapenaeus monoceros) & & $\begin{array}{l}3.87 \pm 1.05 \text { pieces } / g \text { of gastrointestinal tract Filaments } \\
\text { dominant at } 58 \%\end{array}$ & \\
\hline \multirow[t]{2}{*}{ Whiteleg shrimp (Litopenaeus vannamei) } & Malaysia & $20.8 \pm 3.57 / g$ w.w. Film dominant at $97.9 \%$ & This study \\
\hline & Ecuador & $13.4 \pm 1.42 / g$ w.w. Film dominant at $93 \%$ & \\
\hline Argentine red shrimp (Pleoticus muelleri) & $\begin{array}{l}\text { Argentina Southwest Atlantic, } \\
\text { FAO } 41\end{array}$ & $7050 \pm 4178 / g$ w.w Spheres dominant at 69.6\% & \\
\hline $\begin{array}{l}\text { Indian white shrimp (Fenneropenaeus } \\
\text { indicus) }\end{array}$ & Indian ocean, FAO 57 & $5570 \pm 100 / g$ w.w. Spheres dominant at $61.6 \%$ & \\
\hline
\end{tabular}

waters. Currently, no records exist regarding microplastics in the marine waters of Ecuador. In addition, the similar concentrations of microplastics recorded in L. vannamei shrimp from Malaysia and Ecuador could also be due to similar filtration and ingestion rates in both groups of shrimp. In this study, $P$. muelleri was sourced from the Southwestern Atlantic and contained significantly more microplastics more than L. vannamei. The surface water samples of the Southwestern Atlantic had a concentration of 42,600-113,600 particles/L (Severini et al., 2019), which is about $160,000-300,000$ times the concentration of that in Malaysian waters. Microplastic fibers were the most abundant microplastic recorded from the surface waters of the Southwestern Atlantic (Severini et al., 2019). However, the dominance of microfibers was attributed to the high level of harbor activities, which involved boating and fishing. Given that the composition of microplastics differs based on location ( $\mathrm{La}$ Daana et al., 2017). The greater abundance of microplastics in the Atlantic Ocean could be reflected in the increased uptake and hence microplastic abundance in P. muelleri shrimp.

In $P$. muelleri and F. indicus shrimp, spheres were the most abundant type of microplastics. These spheres are likely to be microbeads, which are primary microplastics that are found in cosmetic or personal care products. Due to the small size of these particles, a significant proportion of these microbeads are discharged in the final effluent even after sewage treatment. In addition, these microbeads are non-biodegradable and hence exist in the marine environment for hundreds of years (Olesen et al., 2017). As a result, fouling can take place on the surface of these plastic particles, resulting in them sinking and being deposited on the seafloor (Kaiser et al., 2017). This results in the seafloor being a major sink for microplastics (Fang et al., 2018). Hence, it is common that marine organisms, especially bottom-dwelling detritus feeders, ingest these microbeads. The agglomeration of microbeads was also observed in P. muelleri shrimp (Figure 1D). Due to the interaction of salt with natural organic matter in seawater, it is not uncommon for microbeads in marine environments to aggregate together (Gambardella et al., 2017). Although a very large number of microplastics were observed in $P$. muelleri and $F$. indicus individuals, this was primarily due to the predomination of spheres, which were approximately $15-20 \mu \mathrm{m}$ in diameter.

Although various types of frozen seafood such as clams, mussels, squids and fish are available in the supermarkets of Singapore, only three species of shrimp have been examined 
for their presence of microplastics to date. In other studies, mussels (Mytilus edulis) were examined from the supermarkets in the United Kingdom at 0.7 items/g (Li et al., 2018), mussels (Mytilus edulis; 0.36 items/g) and oysters (Crassostrea gigas; 0.47 items/g) from coastal farms in Europe (Van Cauwenberghe and Janssen, 2014). Scallops (Argopecten purpuratus) obtained from markets in Lima, Peru showed a mean abundance of 2.25 items/individual (De-la-Torre et al., 2019). Market oysters (C. gigas), mussels (M. edulis), clams (Tapes philippinarum) and scallops (Patinopecten yessoensis) from South Korea showed a mean microplastic concentration of 0.15 items/g (Cho et al., 2019). Analysis of bivalves from a market in Shanghai, China showed an abundance of up to 10.5 items/g ( $\mathrm{Li}$ et al., 2015). For data comparison purposes, it is recommended that the method of microplastic analysis be taken into consideration, such as the chemical treatment for tissue digestion, density separation technique and the mode of microplastic identification (Cho et al., 2019). This is because the variation in the techniques of microplastic analysis can influence the abundance of microplastics obtained. Although the methods of analyses were not similar, these studies provide evidence that species of seafood from different parts of the world are contaminated by microplastics in the ocean. This highlights the pervasiveness of marine microplastic pollution and suggests that there are greater implications on food security and human health.

The presence of microplastics in seafood has led to increased concerns regarding its impact on human health (Sharma and Chatterjee, 2017; Smith et al., 2018). Before human consumption, shrimp are usually peeled to remove head and shell. However, the GI tracts of these organisms are not always completely removed, and hence the microplastics that are present in the intestines of shrimp could be passed on to humans through consumption. This is a route of exposure of microplastics to humans that is often discussed in relation to human health and food security (Barboza et al., 2018; Smith et al., 2018; Cox et al., 2019). Microplastics have shown to leach harmful additives (Koelmans et al., 2014; Hermabessiere et al., 2017) and accumulate persistent organic pollutants (POPs) such as phthalates and Bisphenol A (Rochman et al., 2013). Laboratory studies conducted on lugworms have shown that plastic additives are transferred from microplastics to the organism, resulting in a behavioral change (Browne et al., 2013). In another study, Lassen et al. (2015) showed that ingested microplastic particles from toothpaste can be absorbed by the human gastrointestinal tract. However, there are not yet any published studies examining the

\section{REFERENCES}

Alomar, C., and Deudero, S. (2017). Evidence of microplastic ingestion in the shark Galeus Melastomus Rafinesque, 1810 in the continental shelf off the western Mediterranean Sea. Environ. Pollut. 223, 223-229. doi: 10.1016/j.envpol.2017. 01.015

Akhbarizadeh, R., Moore, F., and Keshavarzi, B. (2019). Investigating microplastics bioaccumulation and biomagnification in seafood from the Persian Gulf: a threat to human health? Food Addit, Contam. Part A Chem. Anal. Control Expo. Risk Assess. 36, 1696-1708. doi: 10.1080/19440049.2019.1649473 fate of microplastics from ingested seafood in humans. Hence, more information is required to ascertain the retention and the impact of microplastics from seafood on the human body.

\section{CONCLUSION}

In this study, microplastics were identified in three species of shrimp, L. vannamei, P. muelleri and F. indicus, from four locations, that were obtained from the local supermarket of Singapore. Microplastic fibers, film, fragments and spheres were found in the GI tracts of shrimps. F. indicus has the greatest microplastic abundance per wet weight, followed by P. muelleri and L. vannamei shrimps. This could be reflected by the abundance of microplastics of benthic sediments where they were obtained. The results of this study provide novel evidence that microplastics exist in shrimps. The ingestion of these shrimp is a route of human exposure to microplastics as these organisms are often eaten whole without gut removal. Additional comprehensive surveys of supermarket seafood are crucial to assess the additional routes of microplastic exposure in humans. The findings of this study highlight the pervasiveness of microplastic pollution in commercially available seafood and provide crucial information for fisheries and the aquaculture industry.

\section{DATA AVAILABILITY STATEMENT}

The datasets presented in this study can be found in online repositories. The names of the repository/repositories and accession number(s) can be found in the article/supplementary material.

\section{AUTHOR CONTRIBUTIONS}

All authors listed have made a substantial, direct and intellectual contribution to the work, and approved it for publication.

\section{FUNDING}

This work was partially supported by funds awarded to Dr. Sandric Leong through NUS and was made possible because of the support from members of Team HABs.

Andrady, A. L. (2011). Microplastics in the marine environment. Mar. Pollut. Bull. 62, 1596-1605. doi: 10.1016/j.marpolbul.201 1.05 .030

Barboza, L. G. A., Vethaak, A. D., Lavorante, B. R., Lundebye, A. K., and Guilhermino, L. (2018). Marine microplastic debris: An emerging issue for food security, food safety and human health. Mar. Pollut. Bull. 133, 336-348. doi: 10.1016/j.marpolbul.2018.05.047

Bejgarn, S., MacLeod, M., Bogdal, C., and Breitholtz, M. (2015). Toxicity of leachate from weathering plastics: An exploratory screening study with Nitocra spinipes. Chemosphere 132, 114-119. doi: 10.1016/j.chemosphere.2015.03.010 
Brennecke, D., Duarte, B., Paiva, F., Caçador, I., and Canning-Clode, J. (2016). Microplastics as vector for heavy metal contamination from the marine environment. Estuar. Coast. Shelf Sci. 178, 189-195. doi: 10.1016/j.ecss.2015. 12.003

Browne, M. A., Niven, S. J., Galloway, T. S., Rowland, S. J., and Thompson, R. C. (2013). Microplastic moves pollutants and additives to worms, reducing functions linked to health and biodiversity. Curr. Biol. 23, 2388-2392. doi: 10.1016/j.cub.2013.10.012

Carreras-Colom, E., Constenla, M., Soler-Membrives, A., Cartes, J. E., Baeza, M., Padrós, F., et al. (2018). Spatial occurrence and effects of microplastic ingestion on the deep-water shrimp Aristeus Antennatus. Mar. Pollut. Bull. 133, 44-52. doi: 10.1016/j.marpolbul.2018.05.012

Cau, A., Avio, C. G., Dessì, C., Follesa, M. C., Moccia, D., Regoli, F., et al. (2019). Microplastics in the crustaceans Nephrops norvegicus and Aristeus antennatus: flagship species for deep-sea environments? Environ. Pollut. 255:113107. doi: 10.1016/j.envpol.2019.113107

Cho, Y., Shim, W. J., Jang, M., Han, G. M., and Hong, S. H. (2019). Abundance and characteristics of microplastics in market bivalves from South Korea. Environ. Poll. 245, 1107-1116. doi: 10.1016/j.envpol.2018.11.091

Cole, M., and Galloway, T. S. (2015). Ingestion of nanoplastics and microplastics by Pacific oyster larvae. Environ. Sci. Technol. 49, 14625-14632. doi: 10.1021/ acs.est.5b04099

Cox, K. D., Covernton, G. A., Davies, H. L., Dower, J. F., Juanes, F., and Dudas, S. E. (2019). Human consumption of microplastics. Environ. Sci. Technol. 53, 7068-7074.

Daniel, D. B., Ashraf, P. M., and Thomas, S. N. (2020). Abundance, characteristics and seasonal variation of microplastics in Indian white shrimps (Fenneropenaeus Indicus) from coastal waters off Cochin, Kerala, India. Sci. Total Environ. 737:139839. doi: 10.1016/j.scitotenv.2020.139839

De-la-Torre, G., Mendoza-Castilla, L., and Pilar, R. (2019). Microplastic contamination in market bivalve Argopecten Purpuratus from Lima, Peru. Manglar 16, 85-89. doi: 10.17268/manglar.2019.012

Desforges, J. P. W., Galbraith, M., Dangerfield, N., and Ross, P. S. (2014). Widespread distribution of microplastics in subsurface seawater in the NE Pacific Ocean. Mar. Pollut. Bull. 79, 94-99. doi: 10.1016/j.marpolbul.2013.12. 035

Desforges, J. P. W., Galbraith, M., and Ross, P. S. (2015). Ingestion of microplastics by zooplankton in the Northeast Pacific Ocean. Archiv. Environ. Contamin. Toxicol. 69, 320-330. doi: 10.1007/s00244-015-0172-5

Devriese, L. I., van der Meulen, M. D., Maes, T., Bekaert, K., Paul-Pont, I., Frère, L., et al. (2015). Microplastic contamination in brown shrimp (Crangon Crangon, Linnaeus 1758) from coastal waters of the Southern North Sea and Channel area. Mar. Poll. Bull. 98, 179-187. doi: 10.1016/j.marpolbul.2015. 06.051

Enders, K., Lenz, R., Stedmon, C. A., and Nielsen, T. G. (2015). Abundance, size and polymer composition of marine microplastics $\geq 10 \mu \mathrm{m}$ in the Atlantic Ocean and their modelled vertical distribution. Mar. Poll. Bull. 100, 70-81. doi: 10.1016/j.marpolbul.2015.09.027

Fang, C., Zheng, R., Zhang, Y., Hong, F., Mu, J., Chen, M., et al. (2018). Microplastic contamination in benthic organisms from the Arctic and sub-Arctic regions. Chemosphere 209, 298-306.

Fossi, M. C., Coppola, D., Baini, M., Giannetti, M., Guerranti, C., Marsili, L., et al. (2014). Large filter feeding marine organisms as indicators of microplastic in the pelagic environment: the case studies of the Mediterranean basking shark (Cetorhinus Maximus) and fin whale (Balaenoptera Physalus). Mar. Environ. Res. 100, 17-24. doi: 10.1016/j.marenvres.2014.02.002

Gall, S. C., and Thompson, R. C. (2015). The impact of debris on marine life. Mar. Poll. Bull. 92, 170-179. doi: 10.1016/j.marpolbul.2014.12.041

Gambardella, C., Morgana, S., Ferrando, S., Bramini, M., Piazza, V., Costa, E., et al. (2017). Effects of polystyrene microbeads in marine planktonic crustaceans. Ecotoxicol. Environ. Safety 145, 250-257. doi: 10.1016/j.ecoenv.2017.07.036

Guzzetti, E., Sureda, A., Tejada, S., and Faggio, C. (2018). Microplastic in marine organism: Environmental and toxicological effects. Environ. Toxicol. Pharmacol. 64, 164-171. doi: 10.1016/j.etap.2018.10.009

Hai, T. N., Duc, P. M., Son, V. N., Minh, T. H., and Phuong, N. T. (2015). Innovation in seed production and farming of marine shrimp in Vietnam. World Aquacul. 46, 32-37.
Hermabessiere, L., Dehaut, A., Paul-Pont, I., Lacroix, C., Jezequel, R., Soudant, P., et al. (2017). Occurrence and effects of plastic additives on marine environments and organisms: A review. Chemosphere 182, 781-793. doi: 10. 1016/j.chemosphere.2017.05.096

Hidalgo-Ruz, V., Gutow, L., Thompson, R. C., and Thiel, M. (2012). Microplastics in the marine environment: a review of the methods used for identification and quantification. Environ. Sci. Technol. 46, 3060-3075. doi: 10.1021/es203 1505

Hothorn, T., Bretz, F., Westfall, P., Heiberger, R. M., Schuetzenmeister, A., Scheibe, S., et al. (2016). Package 'Multcomp'. Simultaneous Inference In General Parametric Models. Project For Statistical Computing, Vienna, Austria. Vienna: Project for Statistical Computing.

Hossain, M. S., Rahman, M. S., Uddin, M. N., Sharifuzzaman, S. M., Chowdhury, S. R., Sarker, S., et al. (2020). Microplastic contamination in Penaeid shrimp from the Northern Bay of Bengal. Chemosphere 238:124688. doi: 10.1016/j. chemosphere.2019.124688

Jakimska, A., Konieczka, P., Skóra, K., and Namieśnik, J. (2011). Bioaccumulation of Metals in Tissues of Marine Animals, Part I: the Role and Impact of Heavy Metals on Organisms. Polish J. Environ. Stud. 20:5.

Jory, D., and Cabrera, T. (2012). in Aquaculture: Farming Aquatic Animals And Plants, eds John S. Lucas and Paul C. Southgate (Marine shrimp: Wiley), 476-513.

Kaiser, D., Kowalski, N., and Waniek, J. J. (2017). Effects of biofouling on the sinking behavior of microplastics. Environ. Res. Lett. 12:124003. doi: 10.1088/ 1748-9326/aa8e8b

Kalčíková, G., Alič, B., Skalar, T., Bundschuh, M., and Gotvajn, Ž (2017). Wastewater treatment plant effluents as source of cosmetic polyethylene microbeads to freshwater. Chemosphere 188, 25-31. doi: $10.1016 /$ j.chemosphere.2017.08.131

Kane, I. A., and Clare, M. A. (2019). Dispersion, accumulation, and the ultimate fate of microplastics in deep-marine environments: A review and future directions. Front. Earth Sci. 7:80. doi: 10.3389/feart.2019.00080

Karami, A., Golieskardi, A., Choo, C. K., Romano, N., Ho, Y. B., and Salamatinia, B. (2017). A high-performance protocol for extraction of microplastics in fish. Sci. Total Environ. 578, 485-494. doi: 10.1016/j.scitotenv.2016.10.213

Khalik, W. M. A. W. M., Ibrahim, Y. S., Anuar, S. T., Govindasamy, S., and Baharuddin, N. F. (2018). Microplastics analysis in Malaysian marine waters: A field study of Kuala Nerus and Kuantan. Mar. Poll. Bull. 135, 451-457. doi: 10.1016/j.marpolbul.2018.07.052

Koelmans, A. A., Besseling, E., and Foekema, E. M. (2014). Leaching of plastic additives to marine organisms. Environ. Poll. 187, 49-54. doi: 10.1016/j.envpol. 2013.12.013

La Daana, K. K., Officer, R., Lyashevska, O., Thompson, R. C., and O'Connor, I. (2017). Microplastic abundance, distribution and composition along a latitudinal gradient in the Atlantic Ocean. Mar. Pollut. Bull. 115, 307-314. doi: 10.1016/j.marpolbul.2016.12.025

Lassen, C., Hansen, S. F., Magnusson, K., Noren, F., Hartmann, N. I. B., Jensen, P. R., et al. (2015). Microplastics: Occurrence, Effects And Sources Of Releases To The Environment In Denmark. Copenhagen: The Danish Environmental Protection Agency.

Li, J., Green, C., Reynolds, A., Shi, H., and Rotchell, J. M. (2018). Microplastics in mussels sampled from coastal waters and supermarkets in the United Kingdom. Environ. Pollut. 241, 35-44. doi: 10.1016/j.envpol.2018.05.038

Li, J., Yang, D., Li, L., Jabeen, K., and Shi, H. (2015). Microplastics in commercial bivalves from China. Environ. Pollut. 207, 190-195. doi: 10.1016/j.envpol.2015. 09.018

Luo, H., Xiang, Y., He, D., Li, Y., Zhao, Y., Wang, S., et al. (2019). Leaching behavior of fluorescent additives from microplastics and the toxicity of leachate to Chlorella Vulgaris. Sci. Total Environ. 678, 1-9. doi: 10.1016/j.scitotenv.2019. 04.401

Lusher, A., Hollman, P., and Mendoza-Hill, J. (2017a). "Microplastics in fisheries and aquaculture: status of knowledge on their occurrence and implications for aquatic organisms and food safety," in FAO Fisheries And Aquaculture Technical Paper, (Rome: FAO), 615.

Lusher, A. L., Tirelli, V., O'Connor, I., and Officer, R. (2015). Microplastics in Arctic polar waters: the first reported values of particles in surface and sub-surface samples. Sci. Rep. 5:14947. 
Lusher, A. L., Welden, N. A., Sobral, P., and Cole, M. (2017b). Sampling, isolating and identifying microplastics ingested by fish and invertebrates. Anal. Methods 9, 1346-1360. doi: 10.1039/c6ay02415g

Mace, M. M., and Rozas, L. P. (2018). Fish predation on juvenile penaeid shrimp: Examining relative predator impact and size-selective predation. Estuar. Coasts 41, 2128-2134. doi: 10.1007/s12237-018-0409-4

Matias-Peralta, H. M., Yusoff, F. M., Shariff, M., and Mohamed, S. (2012). A Tropical Harpacticoid Copepod, Nitocra Affinis Californica Lang As an Effective Live Feed for Black Tiger Shrimp Larvae Penaeus Monodon Fabricius. Pertanika J. Tropic. Agric. Sci. 35:4.

Mazurais, D., Ernande, B., Quazuguel, P., Severe, A., Huelvan, C., Madec, L., et al. (2015). Evaluation of the impact of polyethylene microbeads ingestion in European sea bass (Dicentrarchus Labrax) larvae. Mar. Environ. Res. 112, 78-85. doi: 10.1016/j.marenvres.2015.09.009

Napper, I. E., Bakir, A., Rowland, S. J., and Thompson, R. C. (2015). Characterisation, quantity and sorptive properties of microplastics extracted from cosmetics. Mar. Pollut. Bull. 99, 178-185. doi: 10.1016/j.marpolbul.2015. 07.029

Nel, H. A., Dalu, T., and Wasserman, R. J. (2018). Sinks and sources: Assessing microplastic abundance in river sediment and deposit feeders in an Austral temperate urban river system. Sci. Total Environ. 612, 950-956. doi: 10.1016/j. scitotenv.2017.08.298

Neves, D., Sobral, P., Ferreira, J. L., and Pereira, T. (2015). Ingestion of microplastics by commercial fish off the Portuguese coast. Mar. Pollut. Bull. 101, 119-126. doi: 10.1016/j.marpolbul.2015.11.008

Nimrat, S., and Vuthiphandchai, V. (2011). In vitro evaluation of commercial probiotic products used for marine shrimp cultivation in Thailand. Af. J. Biotechnol. 10, 4643-4650.

Nimrat, S., Boonthai, T., and Vuthiphandchai, V. (2011). Effects of probiotic forms, compositions of and mode of probiotic administration on rearing of Pacific white shrimp (Litopenaeus Vannamei) larvae and postlarvae. Anim. Feed Sci. Technol. 169, 244-258. doi: 10.1016/j.anifeedsci.2011.07.003

Olesen, K. B., van Alst, N., Simon, M., Vianello, A., Liu, F., and Vollertsen, J. (2017). Analysis of Microplastics using FTIR Imaging: Application Note. Agilent Appl. Note Environ. 2017:7.

Pirc, U., Vidmar, M., Mozer, A., and Kržan, A. (2016). Emissions of microplastic fibers from microfiber fleece during domestic washing. Environ. Sci. Pollut. Res. 23, 22206-22211. doi: 10.1007/s11356-016-7703-0

Rebouças, R. H., de Sousa, O. V., Lima, A. S., Vasconcelos, F. R., de Carvalho, P. B., dos Fernandes, et al. (2011). Antimicrobial resistance profile of Vibrio species isolated from marine shrimp farming environments (Litopenaeus Vannamei) at Ceará, Brazil. Environ. Res. 111, 21-24. doi: 10.1016/j.envres.2010. 09.012

Robin, R. S., Karthik, R., Purvaja, R., Ganguly, D., Anandavelu, I., Mugilarasan, M., et al. (2020). Holistic assessment of microplastics in various coastal environmental matrices, southwest coast of India. Sci. Total Environ. 703:134947. doi: 10.1016/j.scitotenv.2019.134947

Rochman, C. M., Hoh, E., Hentschel, B. T., and Kaye, S. (2013). Long-term field measurement of sorption of organic contaminants to five types of plastic pellets: implications for plastic marine debris. Environ. Sci. Technol. 47, 1646-1654.

Rohner, C. A., Armstrong, A. J., Pierce, S. J., Prebble, C. E., Cagua, E. F., Cochran, J. E., et al. (2015). Whale sharks target dense prey patches of sergestid shrimp off Tanzania. J. Plankton Res. 37, 352-362. doi: 10.1093/plankt/fbv010

Rosa, R., and Nunes, M. L. (2004). Nutritional quality of red shrimp, Aristeus antennatus (Risso), pink shrimp, Parapenaeus Longirostris (Lucas), and Norway lobster, Nephrops Norvegicus (Linnaeus). J. Sci. Food Agric. 84, 89-94. doi: 10.1002/jsfa.1619

Seuront, L. (2018). Microplastic leachates impair behavioural vigilance and predator avoidance in a temperate intertidal gastropod. Biol. Lett. 14:20180453. doi: $10.1098 / \mathrm{rsbl} .2018 .0453$
Severini, M. D. F., Villagran, D. M., Buzzi, N. S., and Sartor, G. C. (2019). Microplastics in oysters (Crassostrea Gigas) and water at the Bahia blanca Estuary (Southwestern Atlantic): an emerging issue of global concern. Reg. Stud. Mar. Sci. 32:100829. doi: 10.1016/j.rsma.2019.100829

Sharma, S., and Chatterjee, S. (2017). Microplastic pollution, a threat to marine ecosystem and human health: a short review. Environ. Sci. Pollut. Res. 24, 21530-21547. doi: 10.1007/s11356-017-9910-8

Smith, M., Love, D. C., Rochman, C. M., and Neff, R. A. (2018). Microplastics in seafood and the implications for human health. Curr. Environ. Health Rep. 5, 375-386. doi: 10.1007/s40572-018-0206-z

Sriket, P., Benjakul, S., Visessanguan, W., and Kijroongrojana, K. (2007). Comparative studies on chemical composition and thermal properties of black tiger shrimp (Penaeus Monodon) and white shrimp (Penaeus Vannamei) meats. Food Chem. 103, 1199-1207. doi: 10.1016/j.foodchem.2006. 10.039

Steer, M., Cole, M., Thompson, R. C., and Lindeque, P. K. (2017). Microplastic ingestion in fish larvae in the western English Channel. Environ. Pollut. 226, 250-259. doi: 10.1016/j.envpol.2017.03.062

Sujathan, S., Kniggendorf, A. K., Kumar, A., Roth, B., Rosenwinkel, K. H., and Nogueira, R. (2017). Heat and bleach: a cost-efficient method for extracting microplastics from return activated sludge. Arch. Environ. Contamin. Toxicol. 73, 641-648. doi: 10.1007/s00244-017-0415-8

Tey, Y. S., Suryani, D., Emmy, F. A., and Illisriyani, I. (2009). Food consumption and expenditures in Singapore: implications to Malaysia's agricultural exports. Int. Food Res. J. 16, 119-126.

Theilacker, G. H., and Lasker, R. (1974). "Laboratory studies of predation by euphausiid shrimps on fish larvae," in The Early Life History Of Fish, ed. L. H. S. Blaxter (Berlin: Springer), 287-299. doi: 10.1007/978-3-642-658 52-5_25

Tortajada, C., and Zhang, H. (2016). "Food policy in Singapore," in Food Sciences, ed. B. Caitlin (Amsterdam: Elsevier), 1-7. doi: 10.1355/97898143800 96-002

Van Cauwenberghe, L., and Janssen, C. R. (2014). Microplastics in bivalves cultured for human consumption. Environ. Pollut. 193, 65-70. doi: 10.1016/j.envpol. 2014.06.010

Van Cauwenberghe, L., Claessens, M., Vandegehuchte, M. B., and Janssen, C. R. (2015). Microplastics are taken up by mussels (Mytilus Edulis) and lugworms (Arenicola Marina) living in natural habitats. Environ. Pollut. 199, 10-17. doi: 10.1016/j.envpol.2015.01.008

Varadharajan, D., and Pushparajan, N. (2013). Food and Feeding Habits of Aquaculture Candidate a Potential Crustacean of Pacific White Shrimp Litopenaeus Vannamei, South East Coast of India. J. Aquacul. Res. Dev. 2013:4.

Watts, A. J., Lewis, C., Goodhead, R. M., Beckett, S. J., Moger, J., Tyler, C. R., et al. (2014). Uptake and retention of microplastics by the shore crab Carcinus Maenas. Environ. Sci. Technol. 48, 8823-8830.

Wright, S. L., Rowe, D., Thompson, R. C., and Galloway, T. S. (2013). Microplastic ingestion decreases energy reserves in marine worms. Curr. Biol. 23, R1031R1033.

Conflict of Interest: The authors declare that the research was conducted in the absence of any commercial or financial relationships that could be construed as a potential conflict of interest.

Copyright (C) 2020 Curren, Leaw, Lim and Leong. This is an open-access article distributed under the terms of the Creative Commons Attribution License (CC BY). The use, distribution or reproduction in other forums is permitted, provided the original author(s) and the copyright owner(s) are credited and that the original publication in this journal is cited, in accordance with accepted academic practice. No use, distribution or reproduction is permitted which does not comply with these terms. 